\title{
Corrosion behavior of UNS S31803 steel with changes in the volume fraction of ferrite and the presence of chromium nitride
}

\author{
J.C. de Lacerda a,b,*, L.C. Cândido a , L.B. Godefroid ${ }^{a}$ \\ a REDEMAT, Universidade Federal de Ouro Preto, 35400-000 Ouro Preto, MG, Brazil \\ ${ }^{\mathrm{b}}$ Universidade Federal de Itajubá, Campus Itabira, 35900-000 Itabira, MG, Brazil
}

\section{A R T I C L E I N F O}

\section{Article history:}

Received 28 June 2015

Received in revised form

21 September 2015

Accepted 22 September 2015

Available online 25 September 2015

Keywords:

Stainless steel

Polarization

Pitting corrosion

Stress corrosion cracking

\begin{abstract}
A B S T R A C T
The goal of this study was to examine the changes caused in stress corrosion cracking and the critical pitting temperature behavior of a UNS S31803 duplex stainless steel due to variations in the ferrite fraction and the presence of chromium nitride in their microstructure. The steel plates were cold rolled and annealed at $1060^{\circ} \mathrm{C}$. Microstructural variations in the plates were produced by thermal annealing treatments at $1200{ }^{\circ} \mathrm{C}$ and $1300{ }^{\circ} \mathrm{C}$. Steel annealed at $1060{ }^{\circ} \mathrm{C}$ showed greater resistance to stress corrosion cracking than steel annealed at $1300{ }^{\circ} \mathrm{C}$. Steel annealed at $1300{ }^{\circ} \mathrm{C}$ had the lowest critical pitting temperature.
\end{abstract}

Published by Elsevier B.V.

\section{Introduction}

Duplex stainless steels (DSSs) are characterized by their dual microstructure with ferrite $(\alpha)$ and austenite $(\gamma)$ in equal proportions, giving them a good combination of mechanical strength and corrosion resistance [1,2]. To obtain these properties, an appropriate combination of chemical composition and the absence of undesirable intermetallic phases in the microstructure is required [3-7]. Depending on the temperature and exposure time, intermetallic phases, such as $\sigma, \chi, \alpha^{\prime}, \mathrm{M}_{23} \mathrm{C}_{6}$, austenite second phase and chromium nitride, among others, may occur during the manufacturing and applications of DSS [3,5,8-10]. Higher annealing temperatures induce higher ferrite volume fractions in DSS. The content of chromium nitride in the ferrite is increased with the increase of its microstructure volume fraction due to the low solubility of nitrogen in this phase. The chromium nitride precipitates in the ferrite and favors pit nucleation due to the passive film deterioration near the precipitates by chromium depletion in this region [11].

Different electrochemical techniques have been applied to detect the formation of corrosion pits on DSS. Brigham and Tozer [12] first introduced the critical pitting temperature (CPT) in 1973. CPT has been used as an effective indicator for DSS corrosion pitting detection with good reproducibility [13]. The CPT test is performed

\footnotetext{
* Corresponding author at: Universidade Federal de Itajubá, Campus Itabira, 35900-000 Itabira, MG, Brazil.

E-mail address: jlacerda@unifei.edu.br (J.C. de Lacerda).
}

in a given environment where the application of a constant potential causes a simultaneous temperature increase while monitoring the circuit current. CPT is regarded as the temperature at which the start of pit formation is indicated by the transpassive dissolution, as determined through the observation of the sudden current increase. CPT is reduced by the presence of precipitates in DSS [14].

Stress corrosion cracking (SCC) is a phenomenon that occurs due to the synergic action between a stress applied to a material with a high resistance to uniform corrosion, such as stainless steels and aluminum alloys, and a specific corrosive environment, leading to catastrophic fracture. The time to fracture under SCC depends on the following: the applied stress, the concentration and/ or the nature of the corrosive environment, the temperature, the microstructure and the material composition [8,15]. The understanding of the resistance to SCC of a material is very complex and requires multidisciplinary studies involving chemistry (electrochemistry, chemical kinetics and analytical chemistry), metallurgy (mechanical and physical), materials science and mechanics [16].

This study emphasizes the influence of the application of high temperature annealing on the corrosion properties of UNS S31803 stainless steel. Stress corrosion cracking and the critical pitting temperature are examined. The correlations with the microstructure and the previously mentioned corrosion properties are also addressed. 


\section{Experimental}

\subsection{Materials}

The duplex stainless steel UNS S31803 used in this research was supplied by APERAM South America, Timóteo City, Minas Gerais State, Brazil in the form of cold-rolled sheets with dimensions of $1.8 \times 150 \times 300 \mathrm{~mm}^{3}$ and was annealed at $1060{ }^{\circ} \mathrm{C}$. Table 1 shows the chemical composition of the steel as received; the composition was obtained using a CS-400 carbon analyzer and an ARL 4460 optical emission spectrometer (APERAM South America, Timóteo City, Minas Gerais State, Brazil).

\subsection{Annealing treatments}

The annealing treatments were performed to obtain variations in the volume fraction of the ferrite and austenite in the microstructure and to verify any precipitation of the intermetallic phases. The purpose of these heat treatments was to allow for the evaluation of the effects of the microstructural changes mentioned in the corrosion resistance of UNS S31803 duplex stainless steel. The annealing temperatures adopted were $1200{ }^{\circ} \mathrm{C}$ and $1300^{\circ} \mathrm{C}$. These temperatures were chosen because they are critical temperatures to imbalance the equal proportions of the austeniteferrite phase and are the temperatures that typically occur in areas affected by the thermal welds of this steel $[17,18]$.

The sheets were heated individually in an electric resistance furnace until they reached their annealing temperatures $\left(1200^{\circ} \mathrm{C}\right.$ and $1300{ }^{\circ} \mathrm{C}$ ) and were maintained at these temperatures for approximately $120 \mathrm{~s}$. Cooling was performed using a high flow air blower, which provided a high cooling rate. Fig. 1 shows the applied heating and cooling curves for the annealing treatments, including the annealing treatment of the sheet as received. The temperature measurements on the sheets during the heat treatment were performed using fixed thermocouples on the surfaces that were connected to a digital thermometer with a data acquisition system. The high cooling rate was employed to prevent the precipitation of the intermetallic phases, such as $\sigma, \chi$ and $\alpha^{\prime}$.

\subsection{Microstructural analysis}

Steel microstructural analyses were performed using a Leica optical microscope, a Vega 3 Tescan scanning electron microscope (SEM) (Universidade Federal de Ouro Preto, Minas Gerais, Brazil) and a Quanta 3D FEG FEI SEM equipped with focused ion beam (FIB) technology (Center of Microscopy at the Universidade Federal de Minas Gerais, Belo Horizonte, Brazil). Samples taken from the sheets were embedded in Bakelite with the thick longitudinal section exposed. Two types of reagents were used to reveal the microstructure, Behara ( $1 \mathrm{~g}$ of $\mathrm{K}_{2} \mathrm{~S}_{2} \mathrm{O}_{5}$ in $15 \mathrm{ml}$ of $\mathrm{HCl}$ diluted in $85 \mathrm{ml}$ of distilled water) with an exposure time of $20 \mathrm{~s}$ (to reveal $\alpha /$ $\gamma)[2]$ and an electrolyte solution consisting of oxalic acid solution (10\%) at $5 \mathrm{~V}$ at $15 \mathrm{~s}$ to reveal chromium nitride [18]. The sample for the transmission electron microscopy (TEM) blade analysis was extracted using the FIB technology coupled with the SEM.

\subsection{Potentiodynamic polarization}

The potentiodynamic polarization tests were performed in an

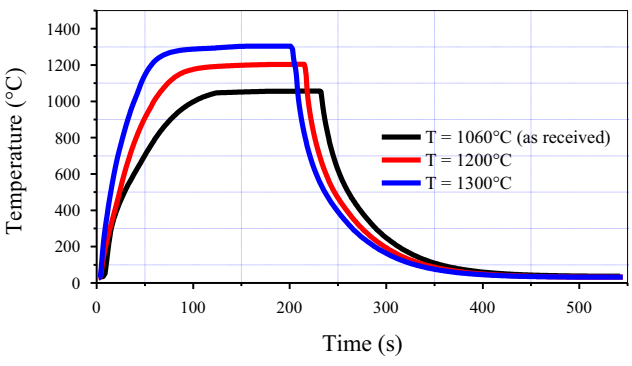

Fig. 1. Annealing applied to UNS S31803 stainless steel.

aqueous solution of sodium chloride $(\mathrm{NaCl})$ at $3.5 \%$ by mass. The reagent solution was prepared with distilled and deionized water under the naturally aerated condition. The specimens for the potentiodynamic polarization tests were prepared from sheets cut to sizes of $1 \mathrm{~cm} \times 1 \mathrm{~cm}\left(1 \mathrm{~cm}^{2}\right)$ with a welded wire length of approximately $15 \mathrm{~cm}$ for the appropriate connections to the potentiostat circuit. The specimens were mounted in polyester resin with an exposed area of $1 \mathrm{~cm}^{2}$, polished with SiC paper with 200 to 600 grit, washed with absolute ethanol and acetone and dried with a hot air jet. Three specimens were prepared for each annealing treatment at $1060^{\circ} \mathrm{C}, 1200^{\circ} \mathrm{C}$ and $1300{ }^{\circ} \mathrm{C}$.

A potentiostat EmStat3 (PalmSens) was used for the potentiodynamic polarization tests. The potential scan was performed from $-400 \mathrm{mV}_{\mathrm{SCE}}$ to $1600 \mathrm{mV}_{\mathrm{SCE}}$ at a scanning rate of $0.167 \mathrm{mV}_{\mathrm{SCE}} / \mathrm{s}$. An electrochemical cell containing three electrodes was used: the reference electrode saturated calomel (SCE), the counter platinum electrode and the working electrode (specimen). The tests were performed at $25^{\circ} \mathrm{C}$ and were repeated for the three specimens.

\subsection{Potentiostatic CPT determination}

Tests were conducted to determine the CPT of the steel UNS S31803 under annealing conditions at $1060{ }^{\circ} \mathrm{C}$ (as received), $1200{ }^{\circ} \mathrm{C}$ and $1300{ }^{\circ} \mathrm{C}$. The tests occurred in a $1 \mathrm{M} \mathrm{NaCl}$ solution. A potentiostat EmStat3 (PalmSens) was used on the three electrodes: the reference electrode saturated calomel (SCE), the counter platinum electrode and the working electrode (specimen). The assembly was performed in a $250 \mathrm{ml}$ beaker, and an electric heater plate was used to heat the solution from $25^{\circ} \mathrm{C}$ to $100{ }^{\circ} \mathrm{C}$. A digital thermometer accurate to $0.1^{\circ} \mathrm{C}$ was used to monitor the solution temperature. The specimens were prepared from a $1 \mathrm{~cm}^{2}$ section of the annealed steel UNS S31803 sheets, and they were welded to a wire and embedded in polyester resin. For testing, the specimens were polished with SiC paper with 200 to 600 grit, washed with absolute ethanol and acetone and dried with a hot air jet. Three specimens were prepared for each annealing treatment at $1060^{\circ} \mathrm{C}$, $1200{ }^{\circ} \mathrm{C}$ and $1300^{\circ} \mathrm{C}$.

To determine the CPT, a constant potential of $750 \mathrm{mV}_{\mathrm{ECS}}$ was applied, and the solution was heated at a rate of approximately $1{ }^{\circ} \mathrm{C} / \mathrm{min}$ [12-14,19-22]. The current densities and temperatures of the respective tests were obtained by software connected to the potentiostat and of the readings on the digital thermometer immersed in the solution. The tests were performed until the current density exceeded $100 \mu \mathrm{A} / \mathrm{cm}^{2}$. The temperature corresponding to this current density value was regarded as the CPT $[13,20]$.

Table 1

Chemical composition of the UNS S31803 duplex stainless steel (wt\%).

\begin{tabular}{|c|c|c|c|c|c|c|c|c|c|c|c|c|c|}
\hline C & $\mathrm{Cr}$ & $\mathrm{Ni}$ & Mo & $\mathrm{N}$ & $\mathrm{Si}$ & $\mathrm{Mn}$ & V & Co & Sn & $\mathrm{Ti}$ & $\mathrm{Nb}$ & $\mathrm{Cu}$ & W \\
\hline 0.02 & 22.38 & 5.35 & 3.04 & 0.15 & 0.31 & 1.82 & 0.06 & 0.02 & 0.01 & 0.04 & 0.04 & 0.20 & 0.01 \\
\hline
\end{tabular}




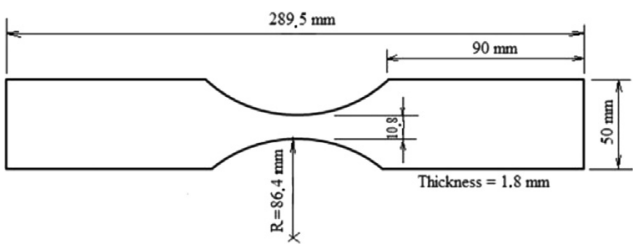

Fig. 2. Specimen for stress corrosion cracking tests.

\subsection{Stress corrosion cracking tests}

Stress corrosion cracking (SCC) tests were performed with a constant tensile load and were used to test samples prepared according to ASTM E-466 [23], as presents in Fig. 2. The stress corrosion cracking tests were conducted with the steel UNS S31803 specimens annealed at $1060{ }^{\circ} \mathrm{C}$ and $1300{ }^{\circ} \mathrm{C}$ and immersed in an aqueous solution of magnesium chloride $\left(\mathrm{MgCl}_{2}\right)$ at $42 \%$ by mass at $143{ }^{\circ} \mathrm{C}$ (boiling temperature of the $\mathrm{MgCl}_{2}$ solution at $42 \%$ by mass). The temperature of the corrosive environment affects the SCC resistance because it increases the kinetics of the corrosion process. The stress values applied in the tests were $223 \mathrm{MPa}, 279 \mathrm{MPa}$ and $335 \mathrm{MPa}$. The applied stresses correspond, on average, to approximately $34 \%, 44 \%$ and $52 \%$ of the steel yield strengths or to $651 \mathrm{MPa}$ and $632 \mathrm{MPa}$ [24], under the annealing conditions at $1060{ }^{\circ} \mathrm{C}$ and $1300^{\circ} \mathrm{C}$, respectively.

For the SCC tests, the specimens were mounted in a cell containing the $\mathrm{MgCl}_{2}$ solution coupled with a condensing system. The ends of the specimens were externally exposed on the cell to the clamping clutches of the testing machine to applying stress $(\sigma)$, as displayed in Fig. 3. An electric heater plate positioned under the cell was used to heat the specimens, and the temperature was monitored by an immersion digital thermometer with a precision of $0.1^{\circ} \mathrm{C}$.

\section{Results and discussion}

\subsection{Microstructural characterization}

In Fig. 4(a), steel in the annealed condition at $1060{ }^{\circ} \mathrm{C}$ shows the typical morphology of a cold rolled duplex stainless steel $[2,25]$. At the other annealing temperatures, as illustrates in Fig. 4 (b) and (c), there was a gradual change in the microstructure morphology as the annealing temperature increased. The flattened morphology of the grains in the steel treated at $1060{ }^{\circ} \mathrm{C}$ caused by lamination decreased with as the annealing temperature increased; there was no evidence of this morphology in steel annealed at $1300{ }^{\circ} \mathrm{C}$.

Duplex stainless steels solidify with $100 \%$ ferrite, and with a decreasing temperature, primary austenite grains are formed in

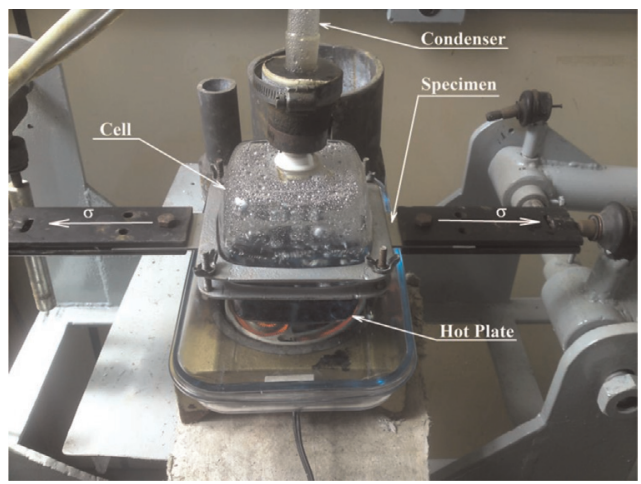

Fig. 3. Assembly of the stress corrosion cracking tests.
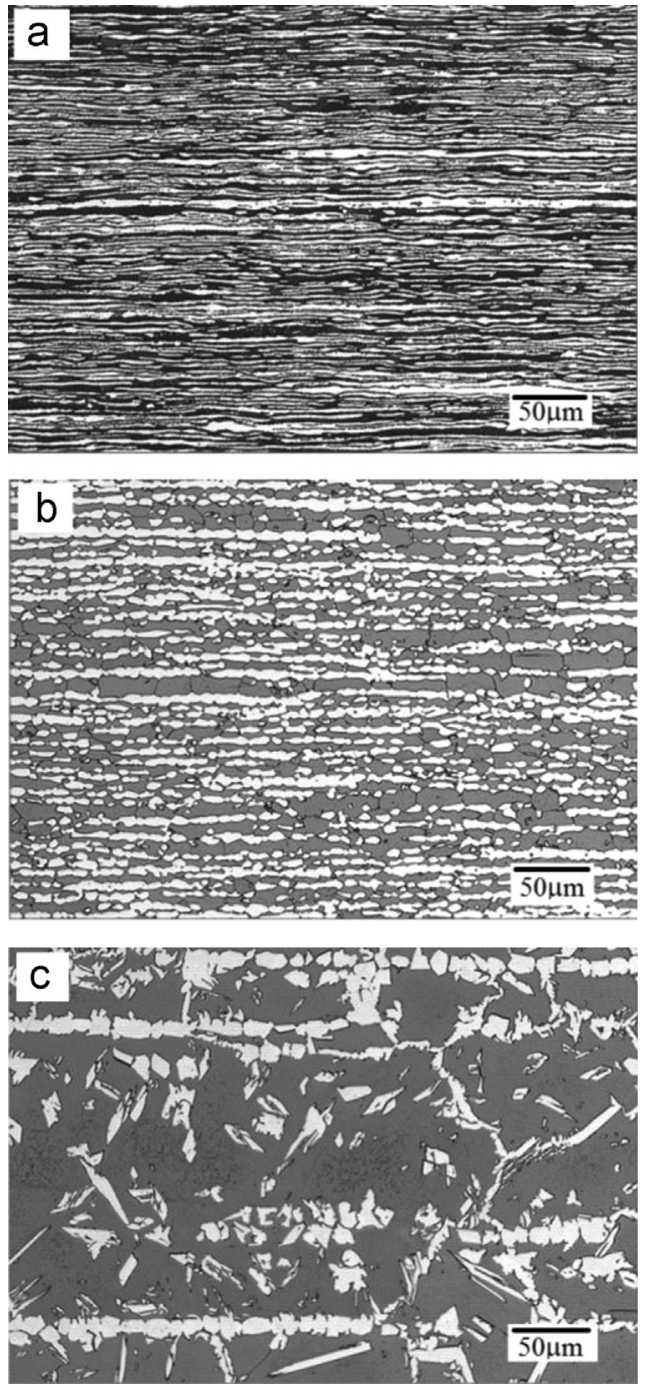

Fig. 4. Optical micrographs of cold rolled UNS S31803 duplex stainless steel: (a) annealed at $1060{ }^{\circ} \mathrm{C}$; (b) annealed at $1200{ }^{\circ} \mathrm{C}$; and (c) annealed at $1300{ }^{\circ} \mathrm{C}$. (dark phase: Ferrite; light phase: austenite).

the ferrite grain boundary by the processes of nucleation and growth [25]. Fig. 4(a)-(c) shows the evolution of the recrystallization process with an increase in the ferrite percentage relative to the austenite with an increasing annealing temperature $\left(51 \pm 2 \%\right.$ in the steel annealed at $1060{ }^{\circ} \mathrm{C}$; $62 \pm 4 \%$ in the steel annealed at $1200{ }^{\circ} \mathrm{C}$; and $74 \pm 3 \%$ in the steel annealed at $1300{ }^{\circ} \mathrm{C}$ ), according to the expected results $[26,27]$.

The volume fraction of ferrite was determined according to ASTM E-562 [28]. An increase in grain size was observed in both microstructures $(\alpha / \gamma)$ with the increasing annealing temperature. The grain size was determined according to ASTM E-112 [29], as presents in Fig. 5.

Precipitates of chromium nitride were collected using an electrolyte solution consisting of oxalic acid (10\%) at $5 \mathrm{~V}$ and $15 \mathrm{~s}$. Chromium nitrides were observed as segregated inside the ferrite grain in the steel sample annealed at $1300^{\circ} \mathrm{C}$, as shown in Fig. 6 .

According to the literature [17,18,26,30,31], chromium nitrides can occur in duplex stainless steels as $\mathrm{Cr}_{2} \mathrm{~N}$ (hexagonal) or $\mathrm{CrN}$ (cubic). The most common form is $\mathrm{Cr}_{2} \mathrm{~N}$. There are reports of the presence of $\mathrm{CrN}$ on welding duplex stainless steel UNS S31803 $[17,32]$. In duplex stainless steels, the precipitation of chromium nitride, typically the $\mathrm{Cr}_{2} \mathrm{~N}$ type, occurs preferentially at the ferriteaustenite interface and can also occur in the boundary ferrite- 


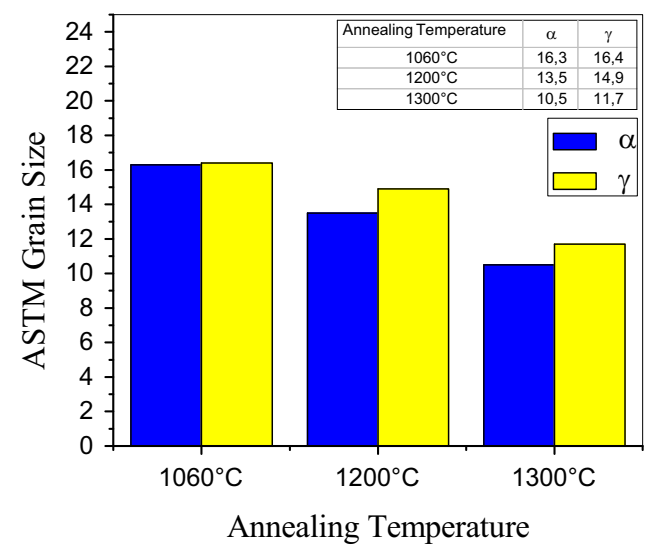

Fig. 5. Variation of the ASTM grain size of $\alpha$ and $\gamma$ of steel UNS S31803.

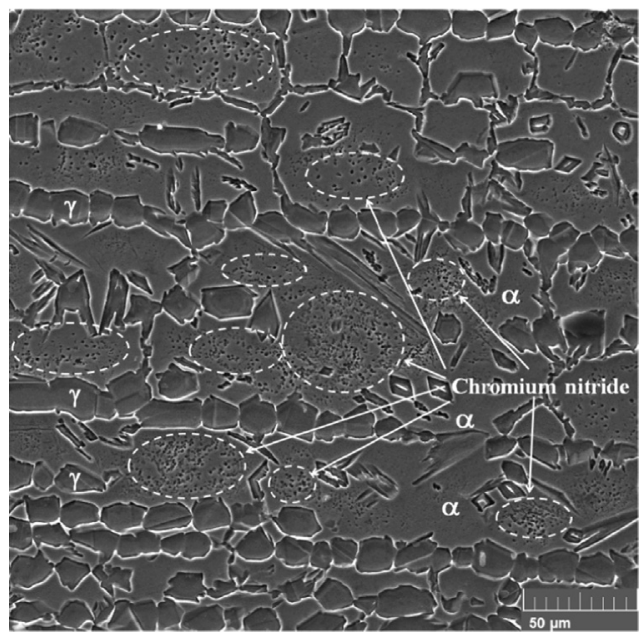

Fig. 6. Microstructure of UNS S31803 stainless steel annealed at $1300{ }^{\circ} \mathrm{C}$. Oxalic acid (10\%) SEM.

ferrite grains [31].

The presence of chromium nitride ( $\mathrm{CrN})$ in UNS S31803 steel annealed at $1300{ }^{\circ} \mathrm{C}$ was confirmed by the TEM image and X-ray diffraction pattern analysis using JEMS software, as shown in Figs. 7 and $8(a)$ and (b).

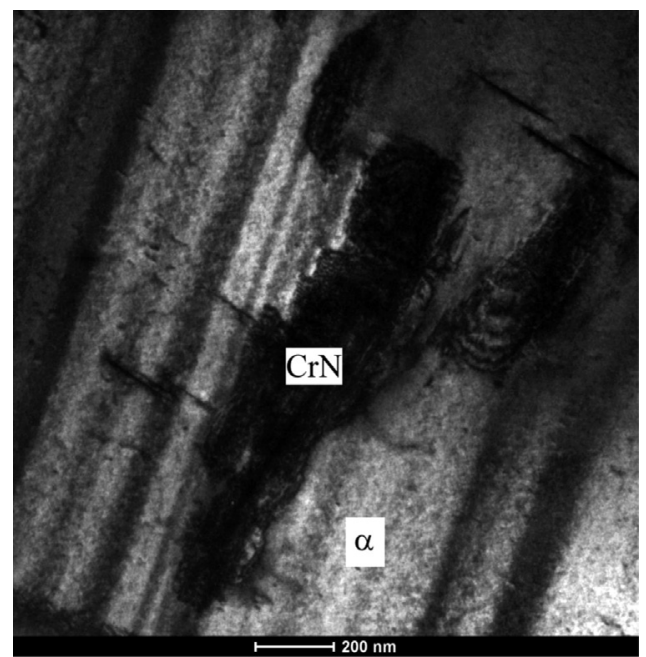

Fig. 7. Chromium nitride ( $\mathrm{CrN})$ on ferrite of UNS S31803 duplex stainless steel annealed at $1300{ }^{\circ} \mathrm{C}(\mathrm{TEM})$.

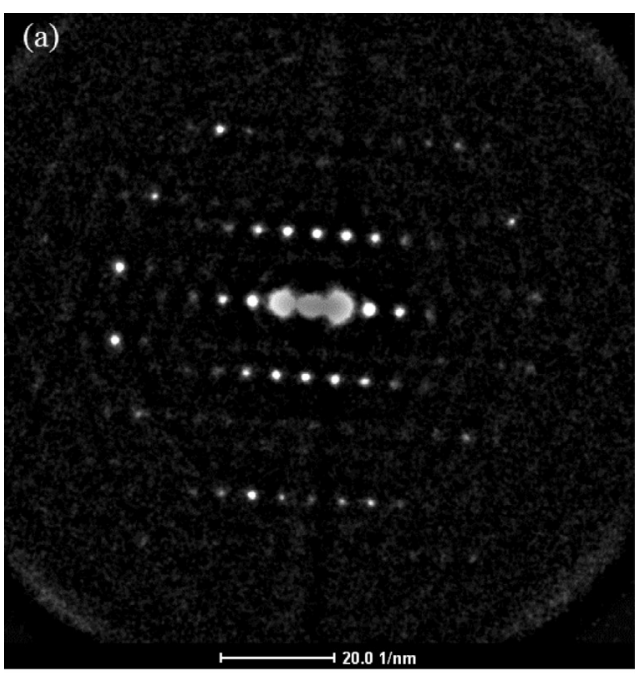

(b)

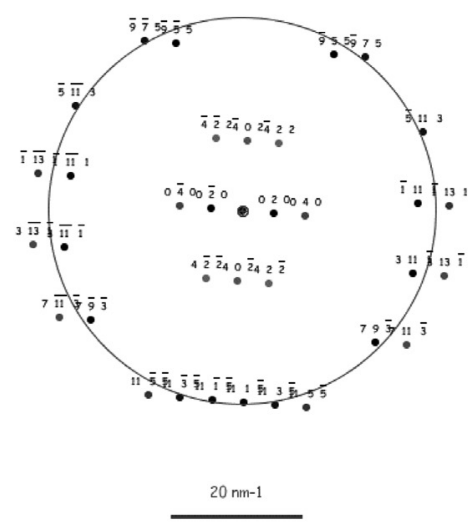

CrN (34 reflections)

$A V / k V: 200.00, C L / m m: 100, Z A:\left[\begin{array}{lll}1 & 0 & 21\end{array}\right.$

Fig. 8. (a) Image of the X-ray diffraction of chromium nitride ( $\mathrm{CrN}$ ) in UNS S31803 steel annealed at $1300{ }^{\circ} \mathrm{C}(\mathrm{TEM})$; (b) standard diffraction of chromium nitride $(\mathrm{CrN})$ simulated by the JEMS software.

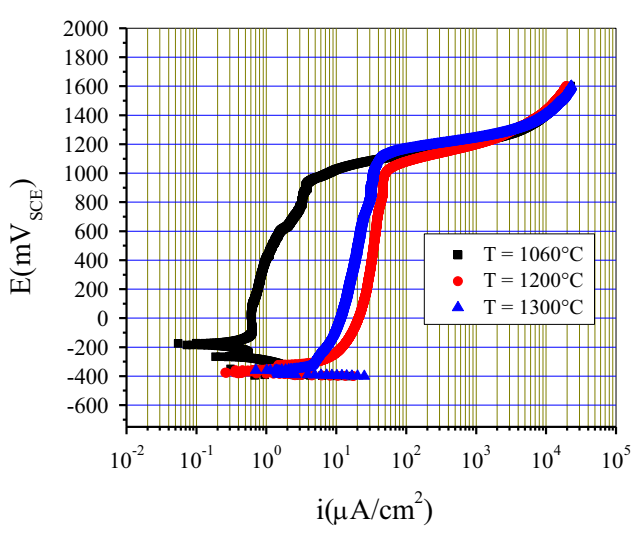

Fig. 9. Potentiodynamic polarization curves of UNS S31803 steel.

Table 2

Potentiodynamic polarization potentials of the UNS S31803 steel.

\begin{tabular}{lrrr}
\hline Annealing Temperature $\left({ }^{\circ} \mathrm{C}\right)$ & \multicolumn{1}{l}{1060} & \multicolumn{1}{c}{1200} & \multicolumn{1}{c}{1300} \\
\hline$E_{\text {cor }}\left(\mathrm{mV}_{\mathrm{SCE}}\right)$ & $-210 \pm 15$ & $-375 \pm 10$ & $-360 \pm 10$ \\
$E_{\text {pit }}\left(\mathrm{mV}_{\mathrm{SCE}}\right)$ & $950 \pm 50$ & $1010 \pm 10$ & $1100 \pm 25$ \\
\hline
\end{tabular}




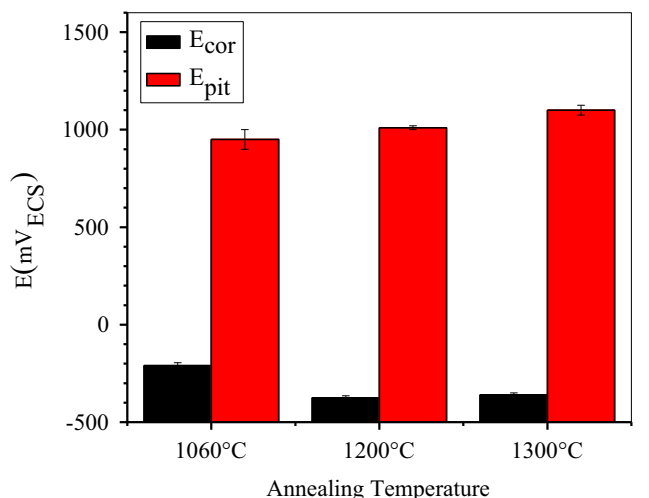

Fig. 10. Variation of the potentiodynamic polarization potentials of the steel UNS S31803.

\subsection{Potentiodynamic polarization potentials}

Fig. 9 presents the potentiodynamic polarization curves of UNS S31803 steel annealed at the temperatures of $1060^{\circ} \mathrm{C}, 1200^{\circ} \mathrm{C}$ and $1300{ }^{\circ} \mathrm{C}$. Table 2 and Fig. 10 show the corrosion potentials $\left(E_{\text {cor }}\right)$ and pit potentials $\left(E_{\mathrm{pit}}\right)$ according to the potentiodynamic polarization curves of the UNS S31803 steel shown in Fig. 9.

According to the data presented in Fig. 10, the increase in pit potential $\left(E_{\text {pit }}\right)$ of UNS S31803 steel occurred as the annealing temperature increased. This behavior is in agreement with finding by Naghizadeh and Moayed [20]. This result reinforces the requirement for further research to explain the increase in $E_{\text {pit }}$, specifically at room temperature. As the annealing temperature increased, the probable reduction in the ferrite PREN (pitting resistance number) [25] was contradictory to the observed increasing $E_{\text {pit }}$. The formation of pits during the potentiodynamic polarization tests is confirmed in the SEM images presents in Fig. 11.

\subsection{Stress corrosion cracking}

Table 3 presents the results of the stress corrosion cracking tests with UNS S31803 steel annealed at $1060{ }^{\circ} \mathrm{C}$ and $1300{ }^{\circ} \mathrm{C}$.

According to Table 3, the increase in the annealing temperature of the UNS S31803 steel from $1060^{\circ} \mathrm{C}$ to $1300{ }^{\circ} \mathrm{C}$ significantly decreased its resistance to stress corrosion cracking. The steel annealed at $1060{ }^{\circ} \mathrm{C}$ for stress lower than $223 \mathrm{MPa}$ can be considered resistant to SCC because for this stress, the steel resisted a $1000 \mathrm{~h}$ SCC test without fracture. However, for higher stress values, the steel presented great fracture susceptibility by SCC, resisting without fracture for a shorter duration. The steel annealed at $1300{ }^{\circ} \mathrm{C}$ was demonstrated to be very susceptible to stress corrosion cracking, even for the lowest applied stress (223 MPa).

The susceptibility of DSS to SCC depends on factors such as alloying elements, microstructure, applied stress and the presence of a corrosive environment $[8,15]$. SCC occurs because initially passivated metal has a stress concentrator; therefore, a slip system is activated and produces a step on the steel surface, increasing the probability of environmental attack on the exposed metal. The combination of the activated slip system, the stress and the restriction on the electrolyte recirculation at the crack tip makes the formation of a passive layer difficult in this region of metal favoring the SCC $[33,34]$. For environments containing chlorides, this emerges as the most acceptable mechanism for anodic dissolution. According to this mechanism, the applied stress tends to break the passive film at the more susceptible points in the heterogeneous metal microstructure. Thus, the exposed metal undergoes attack from the aggressive environment, causing the dissolution of alloy constituents through preferential paths, giving rise to crack nucleation and the successive self-catalytic propagation process [35].
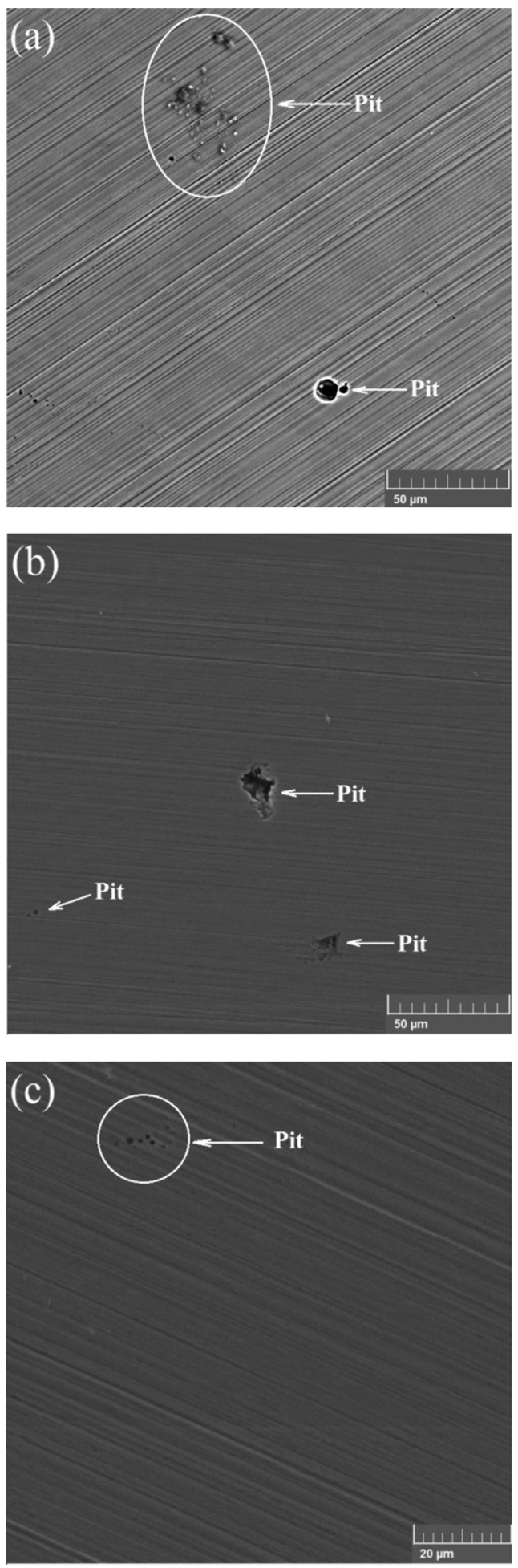

Fig. 11. SEM pits on the surfaces of the annealed specimens after potentiodynamic polarization tests of UNS S31803 steel: (a) $1060{ }^{\circ} \mathrm{C}$; (b) $1200{ }^{\circ} \mathrm{C}$; and (c) $1300{ }^{\circ} \mathrm{C}$.

The evident reduction in SCC resistance of the UNS S31803 steel annealed at $1300{ }^{\circ} \mathrm{C}$ compared with the annealed steel at $1060^{\circ} \mathrm{C}$ can be attributed to the precipitation of chromium nitride that occurred in the ferrite grains of the steel annealed at $1300{ }^{\circ} \mathrm{C}$, as shown in Figs. 6, 7(e) and 8. The precipitation of chromium nitride contributed to the SCC mechanism by favoring the destabilization of the passive film by reducing its chromium content. The destabilization of the passive film subjects the exposed metal to environmental attack. The formation of chromium nitride on the 
Table 3

Time to fracture UNS S31803 steel by stress corrosion cracking under constant load immersed in an aqueous solution of magnesium chloride $\left(\mathrm{MgCl}_{2}\right)$ at $42 \%$ by mass and $143^{\circ} \mathrm{C}$.

\begin{tabular}{lll}
\hline \multirow{2}{*}{ Stress applied (MPa) } & \multicolumn{2}{l}{ Time to fracture $(\mathrm{h})$} \\
\cline { 2 - 3 } & Annealing at $1060{ }^{\circ} \mathrm{C}$ & Annealing at $1300{ }^{\circ} \mathrm{C}$ \\
\hline 223 & 1000 (Not fractured) & $19 \pm 2$ \\
279 & $14.5 \pm 1$ & $4.5 \pm 1$ \\
335 & $9.5 \pm 0.25$ & $3.5 \pm 0.5$ \\
\hline
\end{tabular}

steel annealed at $1300{ }^{\circ} \mathrm{C}$ is justified because during the cooling process of the duplex stainless steel, the austenite phase is formed (by diffusion from the ferrite) below approximately $1300^{\circ} \mathrm{C}$, and in this case, if cooling occurs too quickly, then there is a tendency to obtain a high volume fraction of ferrite relative to austenite. Thus, the precipitation of chromium nitride is highly favored because of the low solubility of nitrogen in ferrite [26]. At lower annealing temperatures, with lower volume fractions of ferrite, it is difficult chromium nitride to form.

Fig. 12(a) and (b) shows the fracture by SSC on the steel annealed at $1300{ }^{\circ} \mathrm{C}$. These figures show the presence of cleavage facets with "river marks," indicating the brittle behavior. The final rupture occurred by mechanically generating the ductile fracture region (the presence of dimples).

\subsection{Critical pitting temperature}

Fig. 13 presents the mean current density curves and the corresponding temperatures of the sodium chloride solution during the tests to determine the CPT. Fig. 14 shows the CPT variation of the UNS S31803 steel.

As determined from Figs. 13 and 14, the UNS S31803 steel annealed at $1300{ }^{\circ} \mathrm{C}$ showed a significant decrease in CPT compared with the same steel annealed at $1060{ }^{\circ} \mathrm{C}$ and $1200{ }^{\circ} \mathrm{C}$. These results occur due to the probable chromium content reduction in ferrite caused by the precipitation of chromium nitride in this phase. Similar results are confirmed in the literature [14,33]. The steel annealed at $1060{ }^{\circ} \mathrm{C}$ and $1200{ }^{\circ} \mathrm{C}$ showed no significant difference of CPT, revealing the low change sensitivity of the volume fraction on this property. The formation of pits during the CPT tests is confirmed in the SEM images presented in Fig. 15.

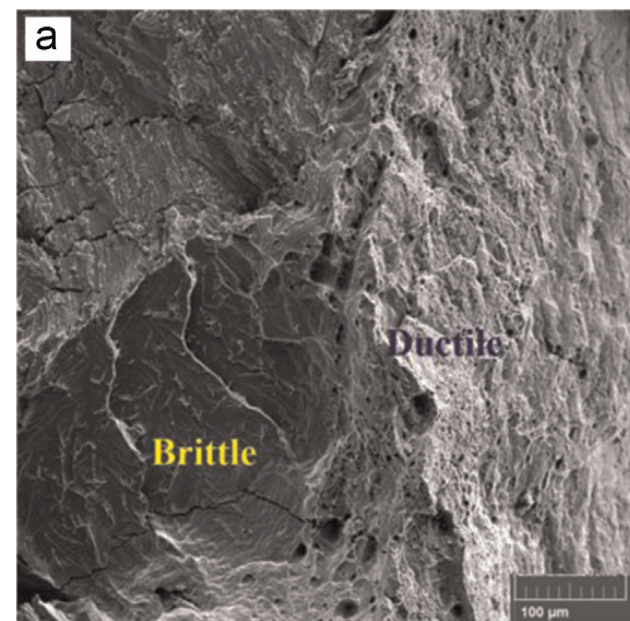

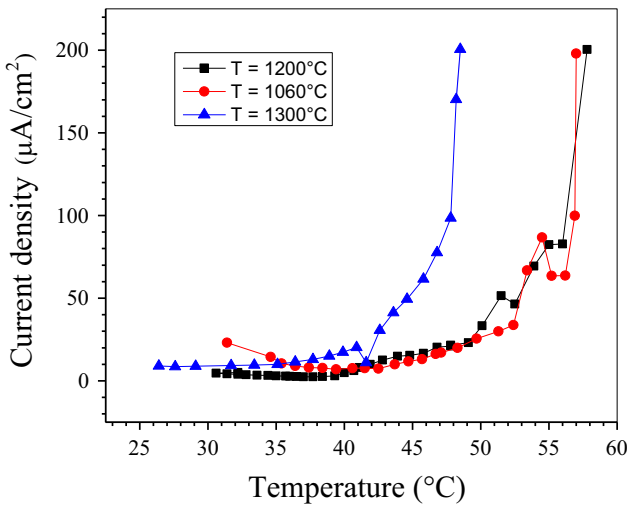

Fig. 13. Current density variation of the UNS S31803 steel as a function of temperature during the CPT tests. $1 \mathrm{M} \mathrm{NaCl}$ solution; $750 \mathrm{mV}_{\mathrm{SCE}}$

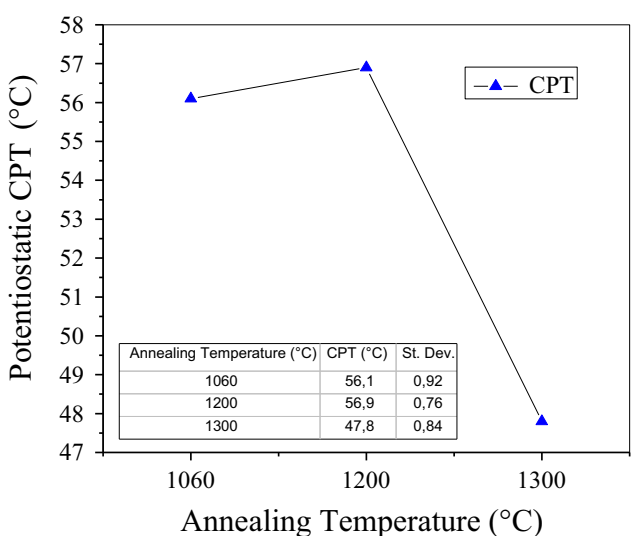

Fig. 14. CPT variation of the UNS S31803 steel annealed at different temperatures $1 \mathrm{M} \mathrm{NaCl}$ solution; $750 \mathrm{mV}_{\mathrm{SCE}}$.

\section{Conclusions}

1. Increasing the annealing temperature of the UNS S31803 steel promoted an increase in its ferrite volume fraction.

2. CrN precipitation occurred in UNS S31803 steel annealed at $1300{ }^{\circ} \mathrm{C}$.

3. UNS S31803 steel annealed at $1060{ }^{\circ} \mathrm{C}$ showed better SCC resistance results compared with steel annealed at $1300^{\circ} \mathrm{C}$.

4. Specimens tested by SCC showed brittle fracture with the

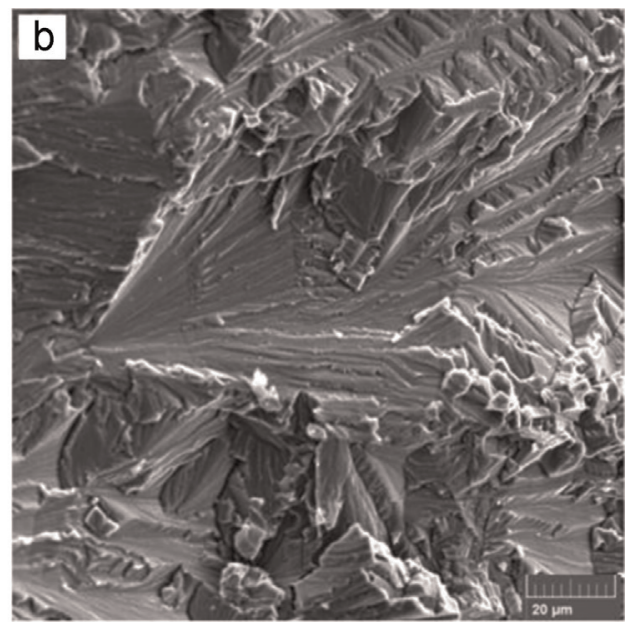

Fig. 12. Fractures by CST. UNS S31803 steel annealed at $1300{ }^{\circ} \mathrm{C}$ (stress applied=223 MPa): (a) transition region of brittle-ductile fracture; and (b) brittle fracture region. SEM. 

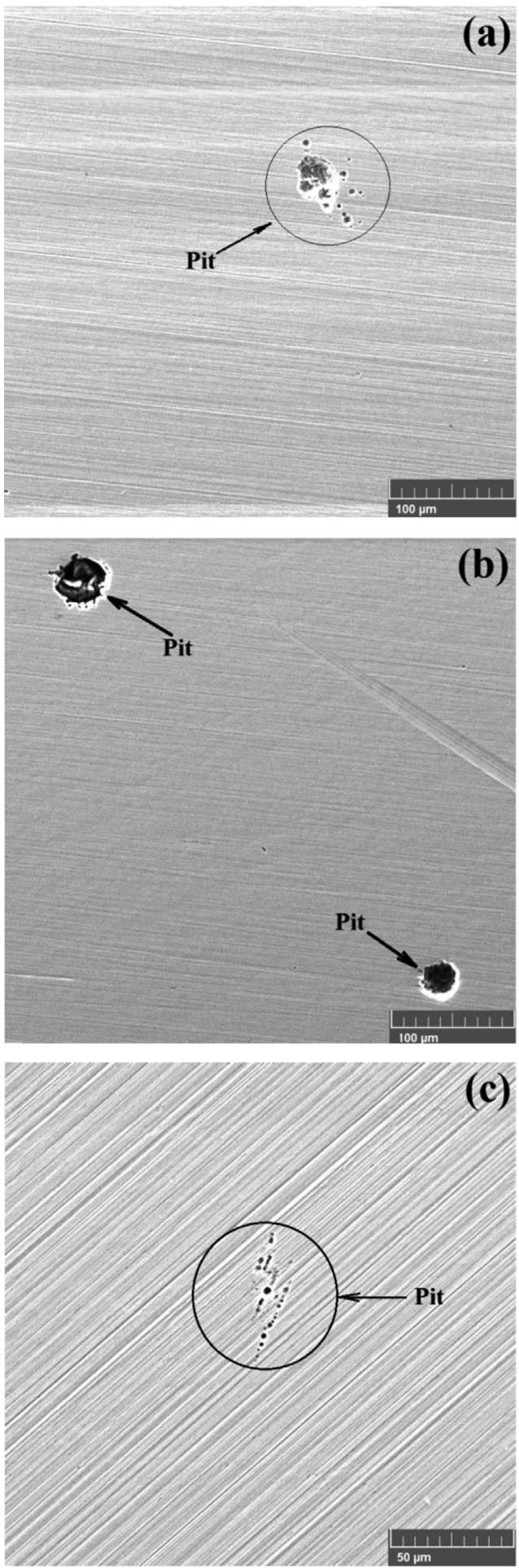

Fig. 15. SEM pits images on the surface of annealed specimens after CPT tests of UNS S31803: (a) $1060^{\circ} \mathrm{C}$; (b) $1200^{\circ} \mathrm{C}$; (c) $1300^{\circ} \mathrm{C}$.

presence of cleavage facets.

5. An increase in the pitting potential $\left(E_{\text {pit }}\right)$ of UNS S31803 steel occurred as the annealing temperature increased to $25^{\circ} \mathrm{C}$.

6. Steel annealed at $1300{ }^{\circ} \mathrm{C}$ showed a reduction in CPT compared with the same steel annealed at $1060{ }^{\circ} \mathrm{C}$ and $1200^{\circ} \mathrm{C}$.

7. Steel annealed at temperatures of $1060{ }^{\circ} \mathrm{C}$ and $1200{ }^{\circ} \mathrm{C}$ showed no significant CPT difference.

\section{Acknowledgments}

The authors would like to acknowledge the Center of Microscopy at the Universidade Federal de Minas Gerais for providing the equipment and technical support for experiments involving electron microscopy. We also thank APERAM South America for the supplied specimens.

\section{References}

[1] J. Gong, Y.M. Jiang, B. Deng, J.L. Xu, J.P. Hu, J. Li, Evaluation of intergranular corrosion susceptibility of UNS S31803 duplex stainless steel with an optimized double loop electrochemical potentiokinetic reactivation method, Electrochim. Acta 55 (2010) 5077-5083.

[2] G. Fargas, M. Anglada, A. Mateo, Effect of the annealing temperature on the mechanical properties, formability and corrosion resistance of hot-rolled duplex stainless steel, J. Mater. Process. Technol. 209 (2009) 1770-1782.

[3] K.H. Lo, C.H. Shek, J.K.L. Lai, Recent developments in stainless steels, Mater. Sci. Eng. R 65 (2009) 39-104.

[4] S. Hereñú, M.G. Moscato, I. Alvarez, A.F. Armas, The influence of chromium nitrides precipitation on the fatigue behavior of duplex stainless steels, Procedia Eng. 74 (2014) 179-182.

[5] S.S.M. Tavares, J.M. Pardal, J.L. Guerreiro, A.M. Gomes, M.R. da Silva, Magnetic detection of sigma phase in duplex stainless steel UNS S31803, J. Magn. Magn. Mater. 322 (2010) 129-133.

[6] M.V. Biezma, C. Berlanga, G. Argandona, Relationship between microstructure and fracture types in a UNS S32205 duplex stainless steel, Mater. Res. 16 (5) (2013) 965-969.

[7] M. Pohl, O. Storz, T. Glogowski, Effect of intermetallic precipitations on the properties of duplex stainless steel, Mater. Charact. 58 (2007) 65-71.

[8] J. Gao, Y. Jiang, B. Deng, W. Zhang, C. Zhong, J. Li, Investigation of selective corrosion resistance of aged lean duplex stainless steel 2101 by non-destructive electrochemical techniques, Electrochim. Acta 54 (2009) 5830-5835.

[9] H.M. Ezuber, A. El-Houd, F. El-Shawesh, Effects of sigma phase precipitation on seawater pitting of duplex stainless steel, Desalination 207 (2007) 268-275.

[10] J.K. Sahu, U. Krupp, R.N. Ghosh, H.J. Christ, Effect of $475{ }^{\circ} \mathrm{C}$ embrittlement on the mechanical properties of duplex stainless steel, Mater. Sci. Eng. A 508 (2009) 1-14.

11] D.H. Kang, H.W. Lee, Study of the correlation between pitting corrosion and the component ratio of the dual phase in duplex stainless steel welds, Corros. Sci. 74 (2013) 396-407.

[12] R.J. Brigham, E.W. Tozer, Temperature as a pitting criterion, Corrosion 29 (1) (1973) 33-36.

[13] M.H. Moayed, N.J. Laycock, R.C. Newman, Dependence of the critical pitting temperature on surface roughness, Corros. Sci. 45 (2003) 1203-1216.

14] B. Deng Z. Wang Y. Jiang, H. Wang. J. Gao, J. Li, Evaluation of localized corrosion in duplex stainless steel aged at $850{ }^{\circ} \mathrm{C}$ with critical pitting temperature measurement, Electrochim. Acta 54 (2009) 2790-2794.

[15] W.T. Tsai, M.S. Chen, Stress corrosion cracking behavior of 2205 duplex stainless steel in concentrated $\mathrm{NaCl}$ solution, Corros. Sci. 42 (2000) 545-559.

[16] P.P. Milella, Fatigue and Corrosion in Metals, Springer, New York, USA, 2013.

[17] E. Betini, U. Kivisäkk, C. Leygraf, J. Pan, Study of corrosion behavior of a $22 \% \mathrm{Cr}$ duplex stainless steel: Influence of nano-sized chromium nitrides and exposure temperature, Electrochim. Acta 113 (2013) 280-289.

[18] S.S.M. Tavares, V.F. Terra, J.M. Pardal, M.P.C. Fonseca, Influence of the microstructure on the toughness of a duplex stainless steel UNS S31803, J. Mater. Sci. 40 (2005) 145-154.

[19] N. Ebrahimi, M. Momeni, A. Kosari, M. Zakeri, M.H. Moayed, A comparative study of critical pitting temperature (CPT) of stainless steels by electrochemical impedance spectroscopy (EIS), potentiodynamic and potentiostatic techniques, Corros. Sci. 59 (2012) 96-102.

[20] M. Naghizadeh, M.H. Moayed, Investigation of the effect of solution annealing temperature on critical pitting temperature of 2205 duplex stainless steel by measuring pit solution chemistry, Corros. Sci. 94 (2015) 179-189.

[21] Z. Zhang, Z. Wang, Y. Jiang, H. Tan, D. Han, Y. Guo, Effect of post-weld heat treatment on microstructure evolution and pitting corrosion behavior of UNS S31803 duplex stainless steel welds, Corros. Sci. 62 (2012) 42-50.

[22] H. Tan, Y. Jiang, B. Deng, T. Sun, J. Xu, J. Li, Effect of annealing temperature on the pitting corrosion resistance of super duplex stainless steel UNS S32750, Mater. Charact. 60 (2009) 1049-1054.

[23] ASTM E-466, Standard practice for conducting force controlled constant amplitude axial fatigue tests of metallic materials 1996.

24] J.C. de Lacerda, L.C. Cândido, L.B. Godefroid, Effect of volume fraction of phases and precipitates on the mechanical behavior of UNS S31803 duplex stainless steel, Int. J. Fatigue 74 (2015) 81-87.

[25] H.Y. Ha, M.H. Jang, T.H. Lee, J. Moon, Interpretation of the relation between ferrite fraction and pitting corrosion resistance of commercial 2205 duplex stainless steel, Corros. Sci. 89 (2014) 154-162.

[26] V.S. Moura, L.D. Lima, J.M. Pardal, A.Y. Kina, R.R.A. Corte, S.S.M. Tavares, Influence of microstructure on the corrosion resistance of the duplex stainless steel UNS S31803, Mater. Charact. 59 (2008) 1127-1132. 
[27] R. Badji, M. Bouabdallah, B. Bacroix, C. Kahloun, B. Belkessa, H. Maza, Phase transformation and mechanical behavior in annealed 2205 duplex stainless steel welds, Mater. Charact. 59 (2008) 447-453.

[28] ASTM E-562, Standard test method for determining volume fraction by systematic manual point count 1995

[29] ASTM E-112, Standard test methods for determining average grain size 1996

[30] N. Sathirachinda, R. Pettersson, S. Wessman, U. Kivisäkk, J. Pan, Scanning Kelvin probe force microscopy study of chromium nitrides in 2507 super duplex stainless steel - implications and limitations, Electrochim. Acta 56 (2011) 1792-1798.

[31] I. Zucato, M.C. Moreira, I.F. Machado, S.M.G. Lebrão, Microstructural characterization and the effect of phase transformation on toughness of the UNS S31803 duplex stainless steel aged treated at $850{ }^{\circ} \mathrm{C}$, Mater. Res. 5 (2002) 385-389.

[32] J.O. Nilsson, Super duplex stainless steel, Mater. Sci. Technol. 8 (1992) 685-700.

[33] M. Gholami, M. Hoseinpoor, M.H. Moayed, A statistical study on the effect of annealing temperature on pitting corrosion resistance of 2205 duplex stainless steel, Corros. Sci. 94 (2015) 156-164.

[34] C.G. Schön, Mecânica dos Materiais, Elsevier, Rio de Janeiro, 2013.

[35] M. Senatore, L. Finzetto, E. Perea, Estudo comparativo entre os aços duplex e os inoxidáveis 304L e 316L., REM: Rev. Esc. Minas 60 (2007) 175-181. 